ks. Józef Zabielski

Uniwersytet Kardynała Stefana Wyszyńnkiego w Warszawie

\title{
Degradacja życia religijno-moralnego jako zagrożenie ładu społeczno-cywilizacyjnego
}

\section{THE DEGRADATION OF RELIGIOUS AND MORAL LIFE AS A THREAT TO CIVIC AND SOCIAL ORDER}

As a personal being, man needs contact with other people in order to fully and properly flourish both personally and socially. This imperative impels man to go "beyond" others and to seek contact with a Transcendental Being, meaning God. Contact with God gives man a sense of safety that enables him to come to know the norms of behavior that stabilize human existence and make proper interpersonal relationships possible. In contemporary society, however, man has departed from this concept, he lives "without God," and is no longer "open to God." Religious and moral indifferentism, or living "as if God does not exist," is a manifestation of such an attitude. When treated as the highest value, materialism becomes the axiological orientation of human existence, which results in the degradation of religious and moral life and threatens social and civic order. This article examines this issue by focusing on two dimensions: 1) the degradation of religious and moral life as a contemporary phenomenon, and 2) the threat to social and civic order that results from religious and moral indifferentism.

Key words: religious and moral indifferentism, turning away from God, practical atheism, degradation of religious and moral life, absolutization of freedom, distorting the truth and the good, threats to social and civic order. 
Natura ludzkiej społeczności oparta jest na relacjach interpersonalnych. Osobowy charakter ludzkiego społeczeństwa wyraża się w rozpoznawaniu i kierowaniu się odpowiednimi normami w decydowaniu i realizacji celów życia. Człowiek jako byt osobowy doświadcza potrzeby kontaktu z kimś poza sobą, co umożliwia mu rozwój osobowo-społeczny. Doświadczenie kontaktu z drugą osobą jednak nie satysfakcjonuje człowieka w pełni, mobilizując go do potrzeby kontaktu z kimś ,ponad” sobą, z Bytem transcendentnym - z Bogiem. Nawiązanie kontaktu z Bogiem daje człowiekowi poczucie bezpieczeństwa, umożliwiając poznanie norm postępowania, co gwarantuje stabilność ludzkiej egzystencji i poprawność relacji międzyludzkich. Fundamentalną normą ludzkiego działania jest miłość, którą chrześcijanie rozpoznają jako wyraz Bożej woli - przykazanie.

Kochać, znaczy dostrzegać pospołu w drugim człowieku wspólne ludzkie przeznaczenie. Jedynie tam, gdzie przeznaczenie człowieka jest pojmowane jako sprawa wspólna, może miłość działać, a prawo kwitnąć. Przeznaczeniem człowieka zaś jest (...) jego otwartość ku Bogu. Stąd też kształt ludzkiej społeczności tylko wtedy jest trwały, gdy ma zasadę w Bogu, ku któremu zdąża wspólne przeznaczenie ludzi. Źródło wzajemnej miłości tryska tam, gdzie ludzie znajdują się w obliczu Boga ${ }^{1}$.

We współczesnych społeczeństwach coraz bardziej zauważa się odchodzenie od takiej koncepcji życia, zaprzepaszcza się „otwartość ku Bogu” i prowadzenie życia „w obliczu Boga”. Ukierunkowaniem ludzkiej egzystencji jest materializm, który

traktowany jest jako wartość, która ukierunkowuje wybory i zachowania ludzi w różnych sytuacjach, nie tylko związanych z konsumpcją per se. (...) W rzeczywistości jednak traktują go jako postawę, a dokładniej zespół przekonań, odnoszących się do trzech zagadnień: przyznawania gromadzeniu rzeczy centralnego miejsca w życiu człowieka, roli dóbr materialnych jako wyznacznika sukcesu życiowego oraz znaczenia posiadania dla poczucia szczęścia i satysfakcji życiowej².

Podejmując analizę tej rzeczywistości w wymiarze zagrożenia ładu społeczno-cywilizacyjnego, chcemy skupić się na dwóch zagadnieniach: 1) Degradacja życia religijno-moralnego jako fenomen

$1 \quad$ W. Pannenberg, Kim jest człowiek, tłum. E. Zwolski i D. Szumska, Paryż 1978, s. 117. Por. S. Gregg, Dignitatis humanae i prawa człowieka, „Zeszyty Naukowe KUL”, 54(2011), nr 1(213), s. 45-59.

2 M. Górnik-Durose, Nowe oblicze materializmu czyli z deszczu pod rynne,, „Psychologia. Edukacja i Społeczeństwo", 2007, t. 4, z. 3, s. 212. Zob. P. C. Phan, Christsein unter kommunistischen oder sozialistischen Regierungen, "Berliner Theologische Zeitschrift”, 27(2010), z. 2, 162-175. 
współczesności; 2) Zagrożenia współczesnego ładu społeczno-cywilizacyjnego jako skutek religijno-moralnego zobojętnienia.

\section{Degradacja życia religijno-moralnego jako fenomen współczesności}

Aksjologicznym podłożem współczesnej degradacji życia religijno-moralnego jest indyferentyzm, stanowiący swoisty „znak czasu” naszej epoki ${ }^{3}$. Ten znak czasu jest dzisiaj pewnikiem w kategorii aksjologiczno-kulturowej.

Nie ma wątpliwości - stwierdza M. Neusch - Bóg przestaje wchodzić w zakres codziennych trosk ludzi. (...) Bóg ustąpił miejsca innym wartościom: opłacalności, wydajności. Kiedy dawniej pojmowano Go jako tego, który daje sens wszelkiej działalności człowieka, dziś odkłada się go do lamusa historii. (...) Na płaszczyźnie codzienności ateizm wyraża się więc stale rosnącą obojętnością, która rozprzestrzenia się, zarażając wszystkie warstwy społeczne. (...) Faktem jest, że coraz więcej ludzi żyje tak, jak gdyby Boga nie było ${ }^{4}$.

Przekonanie to znajduje potwierdzenie w badaniach socjologicznych.

Współczesny indyferentyzm - pisze socjolog religii i moralności J. Mariański - w różnych swoich formach stał się w krajach „chrześcijańskich” Europy Zachodniej zjawiskiem masowym i jakimś „znakiem czasu" naszej cywilizacji, w przeciwieństwie do ateizmu elitarnego epok poprzednich. O ile dawniej indyferentysta był człowiekiem raczej ukrywającym swoje przekonania osobiste, o tyle dzisiaj raczej ludzie wierzący są spychani na margines społeczeństwa. Ateistów i obojętnych religijnie można spotkać we wszystkich kategoriach wieku i we wszystkich kręgach społecznych, a samo zjawisko ma charakter społeczny ${ }^{5}$.

W wymiarze aksjologiczno-kulturowym fenomen religijno-moralnego indyferentyzmu wyróżniają dwa aspekty: zamknięcie na

3 Por. J. Zabielski, Indyferentyzm religijno-moralny jako „znak czasu”, [w:] Ad libertatem in veritate, red. P. Morciniec, Opole 1996, s. 503-520; zob. także: J. Mariański, Religijność w procesie przemian. Szkice socjologiczne, Warszawa 1991.

$4 \quad$ M. Neusch, U źódet wspótczesnego ateizmu, tłum. A. Turowiczowa, Paris 1977, s. 17-18. Por. R. Gilbellini, Jenseites des Atheismus, „Concilium” [niem.], 19(1983), z. 5, s. 401-403.

5 J. Mariański, Religia i Kościół w społeczeństwie pluralistycznym, Lublin 1993, s. 40-41. Por. P. Valadier, Societé moderne et indifférence religieuse, „Catéchese”, 1-4(1988), nr 110-111, s. 63-68; J. Sommet, Die religiöse Gleichgültigkeit der Gegenwart. Erster Entwurf einer Diagnose, "Concilium" [niem.], 19(1983), z. 5, s. 328-367. 
dialog religijny oraz rozmiary tego zjawiska. „Dla religii - stwierdza F. Adamski - ta postać ateizmu jest najbardziej niebezpieczna, bowiem kwestionuje nie tylko możliwość istnienia Boga i poznania Go, ale samo istnienie problemu religii. Jest to zatem ateizm całkowicie niedostępny dla dialogu religijnego" ${ }^{6}$. $\mathrm{Z}$ tym powiązane jest drugie zagrożenie współczesnego indyferentyzmu, jakim są jego rozmiary i sposób oddziaływania. „To już nie powszechność, to «moda», styl bycia, coś, czego zdaje się wymagać wykształcenie lub jakiś nowy Humanizm"7. Opinię tę potwierdza inny socjolog religii:

Indyferentyzm religijny wiąże się z pewnymi cechami współczesnej cywilizacji i tzw. nowoczesnej świadomości oraz zjawiskiem niepokojącym ze względu na rozmiary, jakie przybiera we współczesnym świecie. Przestaje być on tylko sprawą osobistą członków elit intelektualnych, staje się zjawiskiem historycznym o wymiarach światowych ${ }^{8}$.

To narastające oddziaływanie indyferentyzmu powiązane jest z presją form owego zobojętnienia we współczesnym świecie. Wielu ludzi oddaliło się od Boga i religii, ulegając presji owego zobojętnienia. Bóg wydaje się im coraz trudniej dostrzegalny oraz mniej potrzebny do wytłumaczenia problemów osobistych i społecznych. Egzystując w takim środowisku ludzie ci coraz łatwiej ulegają wpływom różnych form religijnego zobojętnienia. Wielu z nich znaczenie religii ogranicza do najważniejszych momentów życia, takich jak narodziny i śmierć ${ }^{9}$.

Zobojętnienie wobec Boga jest też zjawiskiem natury ideowo-moralnej. Ten fenomen współczesności jest wielokrotnie wymieniany w dokumentach Kościoła ${ }^{10}$ oraz pismach teologiczno-filozoficznych. Papież Leon XIII w encyklice Immortale Dei, charakteryzując stan wiary ówczesnego pokolenia, podkreśla zobojętnienie jako szczególną

F. Adamski, Ateizm jakofenomen kulturowy wspótczesnego świata, „Znaki Czasu", 29/30(1993), s. 97. Zob. P. Poupard, Non-cryance et cultures d'aujourd'hui, „Nouvelle Revue Théologique”, 115(1983), nr 1, s. 7-8.

$7 \quad$ F. Adamski, Ateizm jako fenomen kulturowy wspótczesnego świata, s. 97. Por. J. Sommet, Indiffénce religieuse aujourd'hui, „Projekt”, 202(1986), s. 86-87.

8 J. Mariański, Religia i Kościót w społeczeństwie pluralistycznym, s. 83. Por. W. Obrist, L'indifférence religieuse symptôme de la mutation de la conscience, „Concilium” [franc.], 185(1983), s. 67- 68.

$9 \quad$ Por.H.-J.Sander, Lebenszeit-Gottesraum, „Jahrbuch für Biblische Theologie”, 28(2013), s. 323-344. Zob. K. Rahner, La libertà e manipulatione, Bologne 2013.

10 Zjawisko indyferentyzmu szczególnie zauważył papież Pius IX w encyklice Quis pluribus oraz Leon XIII w encyklikach Libertas praestantissiumum i Immortale Dei. Por. V. Miano, L'indifférence religieuse. Etude théologique, „Le Point Théologique", 1983, nr 41, s. 15-16. 
postać niewiary, którą nazywa „ateizmem państwowym” ${ }^{11}$. Sobór Watykański II ukazując życie religijno-moralne XX wieku stwierdza, że są dziś tacy ludzie, którzy „,nie przystępują nawet do zagadnień dotyczących Boga, ponieważ zdają się nie odczuwać niepokoju religijnego i nie pojmują, dlaczego mieliby troszczyć się o religię" ${ }^{2}$. Charakteryzując zaś charakter i zakres tego zjawiska Ojcowie Soboru stwierdzają, że we współczesnym świecie coraz

liczniejsze masy praktycznie odchodzą od religii. W przeciwieństwie do dawnych czasów, odrzucenie Boga czy religii lub odciąganie od nich nie jest już czymś niezwykłym i wyjątkowym; dziś bowiem przedstawia się to nierzadko jako coś, czego wymaga naukowy lub jakiś nowy humanizm ${ }^{13}$.

Ten fenomen współczesności często „przywołuje” Papież Jan Paweł II. Swoistym streszczeniem papieskich wypowiedzi w tym zakresie mogą być słowa z Listu Apostolskiego Tertio millennio adveniente przygotowującego ludzkość na Jubileusz Roku 2000. Przy końcu drugiego tysiąclecia chrześcijaństwa Papież dramatycznie pyta:

Czy można (...) przemilczeć zjawisko obojętności religijnej, która sprawia, ze wielu współczesnych ludzi żyje dziś tak jak gdyby Bóg nie istniał albo zadowala się mglistą religijnością, niezdolną sprostać problemowi prawdy ani obowiązkowi zachowania spójności między życiem i wiarą? Należy do tego dodać także powszechną utratę poczucia etyki, obejmujące nawet tak fundamentalne wartości, jak szacunek dla życia i rodziny ${ }^{14}$.

Zobojętnienie w tym wymiarze ludzkiej egzystencji objawia się w charakterystycznym „oporze przeciw obietnicom wiary”, które wielu ludzi nie pociąga, gdyż dotyczy życia „z innego świata”. To, co głosi i proponuje wiara w Boga i religia nie wydaje się atrakcyjne, godne zaangażowania. Cały ten „niebieski idealizm” wydaje się „mdły” i nierealny, przytłaczający codzienność ludzkiego życia. Wiara religijna nie daje też Ethics „nie ma pomysłu” na zaradzenie trudnościom dnia codziennego oraz wielkim tragediom ludzkości. Z tym powiązana jest „ogólna rezygnacja”

11 Jest to konkluzja opinii Leona XIII na ten temat zawarta w encyklice Immortale Dei.Por.P.Colin,L'indifférence religieuse.Discours ancien, questions nouvelles, „Etudes”, 362(1985), nr 3, s. 397-398.

12 Sobór Watykański II, Konstytucja Gaudium et spes, nr 19.

13 Ibidem, nr 7. Por. Franciszek, Adhortacja Apostolska Evangelii gaudium, nr 6175; G. Girardi, Uwagi o obojętności religijnej, „Concilium” [pol.], 1-10(1966/67), s. 117-118.

14 Jan PawełII, Tertio millennio adveniente, nr 36. Por. Jan PawełII, Homilia podczas Mszy św. z beatyfikacja Rafata Chylińskiego, Warszawa 09.06.1991, [w:] Czwarta Pielgrzymka Jana Pawta II do Polski, Poznań - Warszawa 1991, s. 223. 
z tzw. pytań ostatecznych ludzkiej egzystencji i całego świata - jego sensu, na które tylko wiara religijna może odpowiedzieć. Ludzie tak myślący sądzą, że człowiek jest zdolny poznawać świat tylko w jego „zmysłowych przejawach”, za pomocą nauk przyrodniczych. Wiara zaś i „rzeczywistość religijna” jawi się jako niemożliwa do przyjęcia z „,nowoczesnego" i „,naukowego" punktu widzenia ${ }^{15}$. Takie pojmowanie świata i ludzkich możliwości poznawczych przekłada się na rozpoznawanie praw i norm moralnych. Skoro religijna wiara nie daje odpowiedzi na pytania: skąd jest Bóg i po co On istnieje, to trzeba zachować dystans do Niego jako Najwyższej Wartości i celu naszego życia. Z tym powiązana jest obojętność wobec Boga jako źródła moralności i normatywnego ich charakteru oraz podporządkowania ludzkiego działania woli Boga. Wobec tego, człowiek ma prawo do absolutnej wolności podejmowania decyzji i oceny swego działania. Indyferentyzm jawi się więc jako najbardziej „rozsądna” postawa wobec rzeczywistości niepoznawalnej zmysłowo i niewyjaśnianej przy pomocy tzw. nauk ścisłych ${ }^{16}$.

Konsekwencje tej postawy są niezwykle tragiczne, zwłaszcza w wymiarze wartościowania ludzkiej egzystencji. Ludzie żyjący „tak jakby Boga nie było" tracą poczucie osobistej wartości oraz celowości swego życia i relacji interpersonalnych.

W istocie odrzucając wiarę w Boga, zapominając o Jego bezinteresowności, Jego darach w naszym życiu, to znaczy tracąc naszą pamięć założycielską, zapominając, że On jest naszym początkiem i fundamentem..., staliśmy się bożkami, które chcą zagłębić się same w siebie, by w końcu sprowadzić swoją tożsamość do swoich kaprysów. Ta zachodnia kultura, która w konsekwencji błędnych koncepcji filozoficznych i teologicznych w swej świadomości przestała potrzebować Boga jako podstawy bytu istnienia człowieka, straciła nie tylko wiarę, ale i nadzieją, z nią zaś doskonałośćc ${ }^{17}$.

Ethics

\section{Zagrożenia współczesnego ładu społeczno-cywilizacyjnego jako skutek religijno-moralnego zobojętnienia}

U podstaw deformacji ładu społeczno-cywilizacyjnego sytuuje się „obojętność metodyczna” [,überlegte Gleichgültigkeit”]. Postawa ta

15 Por. K.-H. Weger, Die verdrängte Frage nach Gott, "Stimmen der Zeit", 105(1981), z. 1, s. 35-36.

16 Por. ibidem, s. 36-37. Zob. także: H. R. Schlette, De l'indifférence religieuse a l'agnosticisme, „Concilium” [franc.], 1983, s. 82-87; X. Tiliette, Inquiétude humane et incroyance, „Nouvelle Revue Théologique”, 106(1984), s. 161-176.

17 G. L. Müller, Raport o stanie nadziei, tłum. K. Jasiński, Warszawa 2017, s. 20. 
wyraża się w „naukowym” połączeniu teoretycznej technicyzacji życia z działaniem praktycznym. Sprowadza się to do wykluczenia Boga, religii i moralności z poznania naukowego, traktując te wartości jako irracjonalne, niewarte zainteresowania. W konsekwencji, każdy człowiek ma prawo sam budować struktury życia indywidualnego i społecznego. Zajmowanie się zasadami religijno-moralnymi traktowane jest jako „strata czasu”, zaś obojętność w tym zakresie to „rozsądne” planowanie i realizowanie celów swej egzystencji. Przykładem takiej postawy może być „naukowy” materializm, starający się przekonać ludzkość, że kultura oparta na religii nie dadzą się pogodzić z nowoczesną nauką i społeczno-kulturowym pluralizmem. Człowiek wierzący, np. chrześcijanin, ukazywany jest jako „godny politowania” i potrzebujący „wykształcenia”, aby mógł poznać „prawdę” i być włączony do społeczności ludzi „nowoczesnych”, czyli religijnie obojętnych. Postawa ta wyraża się w przekonaniu o możliwości „samo-zbawienia” przez daną jednostkę lub społeczny kolektyw ${ }^{18}$.

Kolejną postacią deformacji społeczno-kulturowego ładu jest obojętność jako „doświadczenie pustki i nieobecności”. Postawę taką często prezentują ludzie młodzi, którzy „odnajdują się” w tym, że życie w swej fundamentalnej wartości nie posiada żadnego sensu. Takie przeświadczenie pomaga im żyć „na luzie”, będąc przekonanym o aksjologicznej pustce ludzkiej egzystencji. Sprowadza się to do pominięcia odnajdywania sensu swego istnienia i kierowania się stałymi zasadami działania, a skoncentrowaniu się na „chwili obecnej” i życiu codziennością. W takim przeżywaniu „dnia codziennego” wystarczy doświadczenie estetyczne i seksualne, bądź nihilizm „wiecznego powrotu”. Powiązane jest to z „marzeniem” o wszechogarniającym panowaniu śmierci, co u wielu ludzi powoduje „totalne zwątpienie”. Osoby o takiej orientacji aksjologicznej często pytają, jak religia i moralność mogą wyjaśnić i zapobiec różnorodnym cierpieniom świata. Skoro to jest niemożliwe przez życie religijno-moralne, to „rozsądniej” jest zachować obojętność wobec Boga, pogrążając się w „pustce i nieobecności”"19.

Jeszcze groźniejszą postacią współczesnego indyferentyzmu jest „obojętność destrukcji” [„Gleichgültigkeit der Zersetzung”]. Wyraża się to w niemal zupełnym braku zainteresowania życiem „tu i teraz” oraz wartościowania życia w jakimkolwiek znaczeniu. Tę postawę

18 Por. J. Sommet, Die religiöse Gleichgültigkeit der Gegenwart. Erster Entwurf einer Diagnose, „Concilium” [niem.], 19(1983), z. 5, s. 332-333. Zob. J. Troska, Chrześcijaństwo - marksizm. Dialog wokót wartości moralnych, Poznań 1989, s. 141-150; T. Pikus, Rosja w objęciach ateizmu, Warszawa 1997, s. 45-57.

19 Por. J. Sommet, Die religiöse Gleichgültigkeit der Gegenwart..., s. 333; L. Tyrmand, Życie towarzyskie i uczuciowe, Paryż 1967, s. 383. 
spotyka się często w pewnych grupach młodzieży, która opowiada się za całkowitym bezsensem [„Quatsch”]; od tej postawy nie są też wolni ludzie starsi. Osoby te charakteryzuje „wzbranianie się" przed przyjęciem wartości, dla których warto żyć, które „potrafią” nadać sens ludzkiej egzystencji. Postawa ta sprowadza się do „rozkładu własnej osobowości” lub „ucieczki” w skończenie ze sobą przez samobójstwo, alkohol, narkotyki, niszczące przestępstwa. Człowiek taki pozostaje obojętny na wszelkie wartości, nie ma poczucia odpowiedzialności, nie dostrzega istnienia i sensu żadnych ważnych i potrzebnych w życiu norm i zasad. Jest to postawa wyjątkowo groźna i degradująca wszelkie normy społeczno-kulturowe ludzkości ${ }^{20}$. Ludzie młodzi często prezentują swoją obojętność wobec egzystencjalnych norm i wartości w kategoriach typu: ,,jeszcze mi na niczym nie zależy”, ,jeszcze mi wolno", ,jeszcze mam czas". Nie interesuje ich sens i cel życia, a w konsekwencji Bóg, religia, moralne zasady i zobowiązania. W wymiarze społeczno-kulturowym jest bardzo niebezpieczne i deformujące, czego przejawem jest też liczba młodzieży prezentującej taką życiową postawę. Optymistyczne jest to, że młodzież jest u początku swego życia i ma możliwości przemiany. Rozwijając się jednak w środowisku zdeformowanym aksjologicznie, te szanse rozwoju są wątpliwe ${ }^{21}$.

Zobojętnienie wobec Transcendencji, obiektywnej Prawdy i Dobra, stawia człowieka na egzystencjalnej „mieliźnie”, co skutkuje utratą przewodniej idei swego życia oraz uniemożliwia odnalezienie sensu w konkretnych życiowych decyzjach i postawach. Człowiek taki coraz częściej pojmuje siebie i swoje bytowanie na ziemi jako „ślepy przypadek", którego sensu i celu nie może odczytać: nie widzi źródła swego zaistnienia, swojej osobowej godności i działania. Taką postawę V. E. Frankl nazwał „,neurozą naszego czasu”22. Tak określona „egzystencjalna frustracja” przejawia się w wielu postaciach i formach niezwykle groźnych nie tylko osobom jej podlegającym, ale też pozostałym członkom współczesnego społeczeństwa. Wiele bowiem współczesnych ludzi, pozbawionych przez religijno-moralny indyferentyzm

$20 \quad$ Por. J. Sommet, Die religiöse Gleichgültigkeit..., s. 331.

21 Por. ibidem, s. 333; R. Bleinstein, Jugend ohne Religion?, „Stimmen der Zeit”, 117(1992), t. 210, z. 9, s. 577; G. Lescanne, Maturation humaine et croissance de la foi, „Christus”, 37(1990), nr 146, s. 138-142.

22 V.E. Frankl, Das Leiden am sinnlosen Leben, Freiburg 1977, s. 11. Por. Benedykt XVI, Caritas in veritate, $\mathrm{nr}$ 21-33; P. Gilbert, La crise du sens, „Nouvelle Revue Théologique", 116(1994), s. 76-89. 
egzystencjalnego wyznacznika, jako jedyny „sens” widzi w sile i przemocy oraz w wynaturzonych formach swych potrzeb i zachowań ${ }^{23}$.

Z tą egzystencjalną frustracją nierozdzielnie wiąże się inny skutek indyferentyzmu, jakim jest „egzystencjalna pustka” lub „,̇yciowa moda". Wyraża się to w bezsensowności przeżywania czasu i swej egzystencji, gdyż człowiek taki ,utracił samego siebie”. Indyferentysta bowiem prezentuje egzystencjalną „,błahość”, pustkę i ,lotność” zarówno swego istnienia, jak i w odniesieniu do poszczególnych życiowych zadań. Takie ,egzystencjalne znudzenie” przytłacza człowieka, nie dając mu chwilki spokoju, nie interesują go ani sprawy wewnętrzne, ani świat zewnętrzny wraz z życiowymi motywacjami. Ogrania go nuda, prześladuje zwątpienie, odraza do wszystkiego oraz powszechny chaos. Tak znudzonemu człowiekowi wszystko jest obojętne, przeżywany czas i całe życie „rozpływa się między palcami”. Mając na względzie ten problem Jan Paweł II stwierdza:

Wśród kluczowych problemów naszego wieku coraz większej wagi nabierał problem ,sensu”, w miarę jak pustka ideologiczna odbierała człowiekowi punkty odniesienia, czyniąc zeń rozbitka pozbawionego kompasu, miotanego burzą. Człowiek czuje się zagubiony, jeśli jego byt na ziemi nie jest rozjaśniony wiecznym światłem, chroniącym go przed fatalistyczną wizją historii jako ślepego mechanizmu, który prowadzi do zabójczych konfliktów ${ }^{24}$.

Równie niepokojąco tę postawę postrzega W. Kasper, według którego:

Śmierć Boga prowadzi do śmierci człowieka. Stwierdza się zatem współcześnie przerażająca pustkę, bezsens i brak orientacji, co jest najgłębszym źródłem lęków wielu ludzi. Jeszcze bardziej niż ateizm właściwą sygnaturą czasu jest wynikający stąd nihilizm ${ }^{25}$.

Egzystencjalna pustka i frustracja wskazują na jeszcze groźniejszy Ethics skutek indyferentyzmu, jakim jest zagrożenie samego bytu osobowego. Pozbawiając człowieka transcendentnych podstaw, religijno-moralne zobojętnienie niszczy szacunek dla godności osoby i jej istnienia.

$23 \quad$ Por. K.-H. Weger, Die verdrängte Frage nach Gott, art. cyt., s. 40-41; J. Zabielski, Indyferentyzm religijno-moralny a kultura życia i miłości, „Ateneum Kapłańskie", 126(1996), z. 2, s. 213-219.

24 Jan Paweł II, Przemówienie do uczestników sympozjum przedsynodalnego, 31.X.1991r., „L'Osservatore Romano” [pol.], 1(1992), s. 50. Por. P. Gilbert, La crise du sens, „Nouvelle Revue Théologique”, 116((1994), hr 1, s. 89-93.

25 W. Kasper, Bóg Jezusa Chrystusa, tłum. J. Tyrawa, Wrocław 1996, s. 20. Por. D. Sattler, Zeiterleben-Ewigkeiterahnen. Anthropologische Zugänge zurpräsentischen Eschatologie, "Jahrbuch für Biblische Theologie”, 28(2013), s. 345-357. 
Powiązanie między wrażliwością na Transcendencję i osoby byt ludzki jest bezpośrednio jednoznaczny. Jan Paweł II z całą stanowczością stwierdza, że „tracąc wrażliwość na Boga, traci się także wrażliwość na człowieka, jego godność i życie" ${ }^{26}$. Tę prawidłowość przypomniał też Sobór Watykański II: „Stworzenie (...) bez Stworzyciela zanika. (...) Co więcej, samo stworzenie zapada w mroki przez zapomnienie o Bogu”27. W konsekwencji, człowiek „obojętny na Boga” nie jest zdolny postrzegać siebie jako kogoś „przedziwnie odmiennego” od innych istot ziemskich, uznając siebie tylko jako „rzecz” najwyższej rangi, ograniczoną do fizycznej natury. W odniesieniach do siebie i innych ludzi nie traktuje już swej egzystencji jako „wspaniałego daru”, który Bóg powierzył jego odpowiedzialności, żeby strzegł go z miłością i czcił jako rzeczywistość „świętą”. W tej sytuacji życie staje się dla człowieka „rzeczą” traktowaną wyłącznie jako własność, nad którą może swobodnie panować, poddając wszelkim manipulacjom ${ }^{28}$.

$\mathrm{Z}$ „urzeczowieniem” człowiek powiązane są inne zagrożenia ludzkiej egzystencji. Jan Paweł II przypomina, że

gdy wykluczy się odniesienie do Boga, znaczenie wszystkich rzeczy ulega głębokiemu zniekształceniu, a sama natura, przestając być „mater”, czyli matką, zostaje sprowadzona do „materiału”, którym można swobodnie manipulować ${ }^{29}$.

Rozwijając ten problem W. Kasper podkreśla, że

wraz z tajemnicą Boga zanika też tajemnica człowieka. W człowieku widzi się już tylko biologiczną istotę potrzeb albo zespół społecznych stosunków. Gdzie to, co jest większe niż człowiek i jego świat już nie istnieje, tam dochodzi do ideologii całkowitego dopasowania się do świata potrzeb i do społecznych stosunków, tam umiera wolność, tam człowiek w swoim rozwoju cofa się do stanu zmyślnego zwierzęcia, tam kończy się głód i pragnienie bezwarunkowej sprawiedliwości ${ }^{30}$.

W konsekwencji we współczesnej kulturze zaczyna dominować racjonalizm naukowo-techniczny, odrzucający ideę prawdy o stworzeniu, którą należy uznać oraz wymagający uszanowania Boży zamysł wobec człowieka. W ten sposób znikają wszelkie transcendentne i metafizyczne fundamenty praw i norm, ludzie zaś zaczynają kierować się

$26 \quad$ Jan Paweł II, Evangelium vitae, $\mathrm{nr} 21$.

$27 \quad$ Sobór Watykański II, Konstytucja Gaudium et spes, nr 36.

28 Por. Jan Paweł II, Evangelium vitae, nr 22; J. Zabielski, Indyferentyzm religijno-moralny a kultura życia i mitości, s. 120-122.

29 Jan Paweł II, Evangelium vitae, nr 22.

$30 \quad$ W. Kasper, Bóg Jezusa Chrystusa, s. 20. 
„wolnością bez prawa” lub „prawem bez wolności”. Jako przykład kierowania się „prawem bez wolności Jan Paweł II podaje

ideologie konstatujące dopuszczalność jakichkolwiek interwencji w naturę w imię niemal jej „ubóstwiania”, które także tym razem nie dostrzega jej zależności od zamysłu Stwórcy ${ }^{31}$.

Dominujący racjonalizm naukowo-techniczny czyni rozum człowieka jedynym źródłem wszelkich norm ludzkiej egzystencji, nadając mu absolutną autonomię w tym zakresie. Tak pojmowana autonomia ludzkiego intelektu „oznacza tworzenie przez sam rozum wartości i norm moralnych" 32 . W konsekwencji taka autonomia prowadzi do negacji uczestnictwa ludzkiego rozumu w mądrości Stwórcy i Boskiego Prawodawcy, jak też wskazuje na swobodę tworzenia norm moralnych uwarunkowanych jedynie okolicznościami historycznymi oraz potrzebami społeczno-kulturowymi ${ }^{33}$.

Obojętność wobec Transcendencji skutkuje absolutyzacją ludzkiej wolności do tego stopnia, że „,zyni z niej absolut, który ma być źródłem wartości”34. W konsekwencji indywidualnemu sumieniu ,przyznaje się prerogatywy najwyższej instancji osądu moralnego, która kategorycznie i nieomylnie decyduje o tym, co jest dobre, a co złe" ${ }^{35}$. Janusz Królikowski podkreśla, że takie myślenie zanegowało „to wszystko, co stanowi podstawę zmysłu moralnego człowieka, to znaczy zmysł Boga (...) oraz charakter obiektywny porządku moralnego" ${ }^{36}$. U osób obojętnych na Boga zanika nieodzowny wymóg prawdy, a jego miejsce zajmuje kryterium szczerości, autentyczności, ,zgody z samym sobą”, co prowadzi do skrajnie subiektywnych interpretacji ocen moralnych. Rezultatem tej postawy jest osłabienie lub wręcz negacja zależności wolności od prawdy, co prowadzi do zaburzeń życia osobistego i społecznego ${ }^{37}$.

Absolutnie pojmowana wolność, oderwana od prawdy zakotwiczonej w Bogu, objawia się moralnym chaosem w rozpoznawaniu norm

31 Jan Paweł II, Evangelium vvitae, nr 22. Por. P. Ricoeur, Wolność rozsq̨dna I wolność dzika, „Znak”, 22(1970), nr 7-8(193-194), s. 839-859.

32 Jan Paweł II, Encyklika Veritatis splendor, nr 40.

33 Por. ibidem; zob. P. Hünermann, Fides et Ratio - Einst und Jetzt, „Theologische Quartalschrift", 189(2009), z. 3, s. 161-177.

$34 \quad$ Jan Paweł II, Encyklika Veritatis splendor, nr 32.

35 Ibidem.

36 J. Królikowski, Utrata zmystu grzechu, „Homo Dei”, 68(1998), nr 4, s. 31. Por. L. Verecke, Autonomia sumienia a autorytet prawa, „W Drodze”, 2(1987), s. 11-20.

37 Por. Fr. Schroeter, L’autonomie de la volonté: une ideé périmée?, "Freiburger Zeitschrift für Philosophie und Theologie”, 53(2006), nr 3, s. 741-751. 
i etycznym wartościowaniu. Człowiek bowiem wyłącznie w sobie samym upatruje źródło zasad moralnych, tylko od jego woli zależą oceny poszczególnych decyzji i czynów. Zaciera się różnica między dobrem i złem, zanika rozumienie zła jako grzechu, gdyż w postawie indyferentyzmu brakuje odniesienia do Boga i Jego woli, stanowiącej podstawę religijnego wymiaru $z^{\prime 3}{ }^{38}$. Zło i wina ujmowane są wyłącznie w kategoriach psychologiczno-socjologicznych, co sprawcę zła pozwala „wytłumaczyć” i „zrozumieć”. Postawę taką można określić mianem „obojętność moralna”, którą stanowi „bierna obserwacja zła, milcząca na nie zgoda, może być również częścią postawy minimalizmu etycznego wynikającego z formuły negatywnego utylitaryzmu"39. Takiemu wartościowaniu sprzyjają niektóre dziedziny nauk (zwłaszcza psychologia i socjologia), czyniąc okoliczności ludzkiego działania „odpowiedzialnymi” za decyzje i skutki działań podmiotu. Brak transcendentnego i jednoczącego fundamentu istnienia i działania osoby ludzkiej sprawia, że ludzka moralność staje się czymś umownym i zmiennym, a niekiedy wprost iluzorycznym.

Człowiek formułując swoją własną „prawdę" o wymaganiach porządku moralnego i swojej (bez)grzeszności nie tylko wybiera kłamstwo w jakimś poszczególnym czynie czy poszczególnej postawie, ale czyni je pierwszoplanowym i arbitralnym kryterium swego życia do tego stopnia, że sam staje się „uosobionym kłamstwem”"

Papież Jan Paweł II przypomina: „Bez Boga pozostają ruiny ludzkiej moralności. Każde prawdziwe dobro człowieka - a to jest sam rdzeń moralności - jest tylko wówczas możliwe, kiedy czuwa nad nim Ten Jeden, który sam jest Dobry"41.

Religijno-moralny indyferentyzm powoduje rozpowszechnianie się indywidualizmu, utylitaryzmu i hedonizmu. Zerwana bowiem jedność z Transcendencją sprawia , że wartość natury „być” ustępuje wartości „mieć”. W konsekwencji jedynym celem życia staje się osobisty dobrobyt materialny. „Jakość życia” wyznacza wydajność ekonomiczna, nieuporządkowany konsumpcjonizm, atrakcje i przyjemności fizyczne,

38 Por. J. Römelt, Schulderfahrung als Krise. Zur anthropologischen und theologischen Hermeneutik menschlicher Schuld, "Theologie und Glaube", 81(1991), nr 4, s. 463-466; Z. J. Zdybicka, Autonomia sumienia a nakazy religijne, "Roczniki Filozoficzne", 28(1980), nr 2, s. 119-125.

39 J. Górnicka, Obojętność i nie-działanie jako przedmiot moralnej oceny, „Etyka”, 30(1997), s. 133. Por. J. Römelt, Schulderfahrung als Kirse..., s. 156-160.

$40 \quad$ J. Królikowski, Utrata zmystu grzechu, s. 38.

41 Jan Paweł II, Homilia, Koszalin, 01.06.1991, [w:] Czwarta Pielgrzymka Jana Pawła II do Polski, Poznań - Warszawa 1991, s. 15. 
pomijane są głębsze - duchowo religijne - wymiary ludzkiej egzystencji. Jan Paweł II podkreśla, że

zwłaszcza ludzie młodzi, przytłoczeni świadomością przemijania, próbują „zdobywać” jak najmocniejsze i przynoszące największą satysfakcję osobiste doznania i doświadczenia emocjonalne, co powoduje, że w obliczu wezwania do wyboru drogi życiowej, uwzględniającej wymiar duchowy i religijny oraz potrzebę solidarności, pozostają z konieczności obojętni i niemal sparaliżowani ${ }^{42}$.

Ta zgubna postawa indyferentyzmu wpływa na formację sumienia, w którym człowiek podejmuje decyzje moralne i wartościuje czyny. Należy mieć na uwadze sumienie indywidualne oraz społeczne. Ludzi, którzy odwrócili się od Boga i mniemają, że ziemską społeczność mogą budować bez Stwórcy, ,przez nieprawość nakładają prawdzie pęta" (Rz 1,18) oraz znikczemnieli w swoich myślach do tego stopnia, że „zaćmione zostało bezrozumne ich serce” ( $R z$ 1,21); „podając się za mądrych, stali się głupimi" ( $\mathrm{Rz} 1,22)$, popełniają czyny zasługujące na śmierć, a „nadto chwalą tych, którzy je czynią” ( $\mathrm{Rz} 1,32)$. Bardzo trafne jest sumujące stwierdzenie Jana Pawła II: „W rzeczywistości, żyjąc tak «jakby Bóg nie istniał» człowiek zatraca nie tylko tajemnicę Boga, ale również tajemnicę świata i swojego istnienia"43.

\section{DEGRADACJA ŻYCIA RELIGIJNO-MORALNEGO JAKO ZAGROŻENIE ŁADU SPOŁECZNO-CYWILIZACYJNEGO}

Człowiek jako byt osobowy do pełnego rozwoju potrzebuje kontaktu z innymi osobami, co umożliwia mu poprawny rozwój osobowo-społeczny. Ten imperatyw sięga „ponad" osobę drugiego człowieka, dążąc do kontaktu z Bytem Transcendentnym - z Bogiem. Kontakt z Bogiem daje człowiekowi poczucie bezpieczeństwa, umożliwiając poznanie norm postępowania, stabilizujących ludzką egzystencję i poprawność relacji międzyludzkich. We współczesnym społeczeństwie mamy do czynienia z odchodzeniem od tej koncepcji, gubieniem „otwartości ku Bogu” i prowadzeniem życie „bez Boga”. Postawę taką prezentuje religijno-moralny indyferentyzm, czyli życie „jakby Boga nie było”. Aksjologicznym ukierunkowaniem ludzkiej egzystencji staje się materializm, traktowany jako wartość najwyższa. Skutkuje to degradacją życia religijno-moralnego oraz prowadzi do licznych zagrożeń ładu społeczno-cywilizacyjnego. Podejmując analizę tego zagadnienia, w niniejszym artykule chcemy skupić

\footnotetext{
42 Jan Paweł II, Adhortacja Apostolska Pastores dabo vobis, nr 7.

$43 \quad J a n$ Paweł II, Evangelium vitae, nr 22. Por. D. Seeber, Hat das Christentum Zukunft?, "Herder Korrespondenz", 45(1991), z. 5, s. 197-200.
} 
się na dwóch jego wymiarach: 1) Degradacja życia religijno-moralnego jako fenomen współczesności; 2) Zagrożenia ładu społeczno-cywilizacyjnego jako skutek religijno-moralnego zobojętnienia.

Słowa kluczowe: religijno-moralny indyferentyzm, odchodzenie od Boga, ateizm praktyczny, degradacja życia religijno-moralnego, absolutyzacja wolności, deformacja prawdy i dobra, zagrożenia ładu społeczno-cywilizacyjnego.

\section{Bibliografia:}

1. Adamski F., Ateizm jako fenomen kulturowy wspótczesnego świata, „Znaki Czasu". 29/30(1993), s. 92-103.

2. Benedykt XVI, Encyklika Caritas in veritate.

3. Bleinstein T., Jugend ohne Religion?, „Stimmen der Zeit”, 117(1992), t. 210, z. 9, s. 570-581.

4. Colin P., L'indifférence religieuse. Discurs ancient questions nouvelles, „Etudes”, 362(1985), nr 3, s. 392-403.

5. Franciszek, Adhortacja Apostolska Evangelii gaudium.

6. Gilbellini R., Jenseites des Atheismus, „Concilium” [niem.], 19(1983), z. 5, s. 400-408.

7. Girardi G., Uwagi o obojętności religijnej, „Concilium” [pol.], 1-10(1966/67), s. $110-118$.

8. Gilbert P., La crise du sens, „Nouvelle Revue Théologique”, 116(1994), s. $76-89$.

9. Górnicka J., Obojętność $i$ nie-działanie jako przedmiot moralnej oceny, „Etyka”, 30(1997), s. 130-138.

10. Hünermann P., Fides et Ratio - Einst und Jetzt, „Theologische Quartalschrift", 189(2009), z. 3, s. 161-177.

11. Jan Paweł II, Tertio millennio adveniente.

12. Jan Paweł II, Pastores dabo vobis.

13. Jan Paweł II, Humanae vitae.

14. Jan Paweł II, Evangelium vitae.

15. Jan Paweł II, Veritatis splendor.

Ethics

16. Jan Paweł II, Homilia, Kalisz, 01.06.1991, [w:] Czwarta pielgrzymka Jana Pawta II do Polski, Poznań - Warszawa 1991, s. 14-15.

17. Jan Paweł II, Homilia podczas Mszy św. z beatyfikacja Rafata Chylińskiego, Warszawa 09.06.1991, [w:] Czwarta pielgrzymka Jana Pawta II do Polski, Poznań - Warszawa 1991, s. 221-223.

18. Kasper W., Bóg Jezusa Chrystusa, tłum. J. Tyrawa, Wrocław 1996.

19. Królikowski J., Utrata zmystu grzechu, „Homo Dei”, 68(1998), nr 4, s. 28-37.

20. Lescanne G., Maturation humane et croissance de la foi?, „Christus”, 37(1990), nr 146, s. 138-142.

21. Mariański J., Religia i Kościół w społeczeństwie pluralistycznym, Lublin 1993.

22. Miano V., L'indifférence religieuse. Etude théologique, „La Point Théologique", 1983, nr 41, s. 10-18.

23. Müller G. L., Raport o stanie nadziei, tłum. K. Jasiński, Warszawa 2017. 
24. Neusch M., U źródet wspótczesnego ateizmu, tłum. A. Turowiczowa, Paris 1977.

25. Obrist W., L'indifférence religieuse symptôme de la mutation de la conscience, „Concilium” [franc.], 185(1983), s. 65-78.

26. Phan P. C., Christsein unter kommunistischen oder sozialistischen Regierung, „Berliner Theologische Zeitschrift”, 27(2010), z. 2, s. 162-175.

27. Poupard P., Non-croyance et culture d'aujourd'hui, „Nouvelle Revue Théologique", 115(1983), nr 1, s. 3-11.

28. Rahner K., La libertà e manipulatione, Bologne 2013.

29. Römelt J., Schulderfahrung als Krise. Zur anthropologischen und theologischen Hermeneutik menschlicher Schuld, „Theologie und Glaube”, 81(1991), nr 4, s. 461-468.

30. Sander H.-J., Lebenszeit - Gottesraum, „Jahrbuch für Biblische Theologie", 28(2013), s. 323-344.

31. Sattler D., Zeiterleben - Ewigkeit erahne. Antropologische Zugänge zur präsentische Eschatologie, „Jahrbuch für Biblishce Theologie”, 28(2013), s. 345-357.

32. Schlette H. R., De J'indifférence religieuse a l'agnosticisme, „Concilium” [franc.], 1983, s. 82-87.

33. Schroeter Fr., L’autonomie de la volonté: une idée périée?, „Freiburger Zeitschrift für Philosophie und Theologie", 53(2006), nr 3, s. 741-751.

34. Seeber D., Hat das Christentum Zukunft?, „Herder Korrespondenz”, 45(1991), z. 5, s. 197-200.

35. Sobór Watykański II, Konstytucja Gaudium et spes.

36. Sommet J., Die religiöse Gleichgültigkeit der Gegenwart. Erster Enwurf einer Diagnose, „Concilium” [niem.], 19(1983), z. 5, s. 328-367.

37. Sommet J., Indifférence religieuse aujourd'hui, „Projekt”, 202(1986), s. 82-103.

38. Tiliette X., Inquiétude humane et incroyance, „Nouvelle Revue Théologique", 106(1984), s. 166-176.

39. Troska J., Chrześcijaństwo - marksizm. Dialog wokót wartości moralnych, Poznań 1989.

40. Weger K.-H., Die verdrängte Frage nach Gott, „Stimmen der Zeit”, 105(1981), z. 1, s. 30-38.

41. Zabielski J., Indyferentyzm religijno -moralny jako,,znak czasu”, [w:] Ad libertatem in veritate, red. P. Morciniec, Opole 1996, s. 503-520.

42. Zabielski J., Indyferentyzm religijno-moralny a kultura życia $i$ miłości, „Ateneum Kapłańskie”, 126(1996), z. 2, s. 213-219. 